\title{
Photosynthetic analyses of two native Atlantic Forest species in regenerative understory of eucalyptus plantation
}

\section{Frederico Lage-Pinto ${ }^{1 *}$, Elaine Bernini², Jurandi Gonçalves de Oliveira ${ }^{3}$, Angela Pierre Vitória ${ }^{1}$}

'Laboratório de Ciências Ambientais, Centro de Biociência e Biotecnologia, Universidade Estadual do Norte Fluminense, Campos dos Goytacazes, RJ, Brazil.

2Departamento de Engenharia e Meio Ambiente, Centro de Ciências Aplicadas e Educação, Universidade Federal da Paraíba - Campus IV, Rio Tinto, PB, Brazil.

${ }^{3}$ Laboratório de Melhoramento Genético Vegetal, Centro de Ciências e Tecnologias Agropecuárias, Universidade Estadual do Norte Fluminense, Campos dos Goytacazes, RJ, Brazil.

*Corresponding author: fredlage1@gmail.com

Received: 02 May 2012; Accepted: 17 July 2012

\begin{abstract}
Gas exchange, chlorophyll afluorescence, and photosynthetic pigments of Xylopia sericea A. St.-Hil. and Siparuna guianensis Aubl. were evaluated during the rainy season and the dry season (2009-2010) in three understories with different ecological conditions (irradiance, water availability, and temperature) located in the União Biological Reserve (known as REBIO União), at Rio de Janeiro State, a natural forest understory, eucalyptus understory under regeneration, and understory of eucalyptus plantation with 18-year-old trees that were removed 1 year before. The lowest values of $F_{\mathrm{v}} / F_{\mathrm{m}}$ e $F_{\mathrm{m}} / F_{0}$ were observed in the exposed understory for both seasons, with lower values in the dry season, suggesting that reduced water availability potentializes the photoinhibitory process. For both species of the exposed understory it is suggested the occurrence of photoprotection, given that an increased proportion of carotenoid pigments in relation to the chlorophylls were verified. Both species still exhibited dynamic photoinhibition after 1 year of exposure to full sunlight (exposed understory) in both seasons, but more markedly so in the dry season, though they belong to early stages of ecological succession. Based on the results, it is suggested that these species are indicated for planting in degraded areas and that the cutting of eucalyptus trees as management practice should be performed in a gradual manner, during the rainy season, in order to minimize stress on these species.
\end{abstract}

Keywords: Corymbia citriodora, dehydration, photoinhibition, Siparuna guianensis, Xylopia sericea

Abbreviations: $A$ : net photosynthetic rate; $C_{i}$ : internal $\mathrm{CO}_{2}$ concentration; DMSO: organic solvent dimethylsulfoxide; $E$ : transpiration; ETR: electron transport rates; $g_{s}$ : stomatal conductance; IWUE: intrinsic water-use efficient; MANOVA: multifactorial analysis of variance; NPQ: non-photochemical dissipation; PSII: photosystem II; qP: photochemical dissipation; ROS: reactive oxygen species. 


\section{INTRODUCTION}

The elevated incidence of solar radiation and the low water availability of the soil are foremost among the factors that limit the establishment and productivity of the plants. The excessive increase in the incidence of light above the utilization capacity of photosynthesis can promote a condition of stress known as 'photoinhibition' (Barber and Anderson, 1992). Photoinhibition can be detected in alterations in the assimilation of $\mathrm{CO}_{2}$ and in the emission of chlorophyll a fluorescence, characterized by a reduction in the amount of photosynthesis that occurs accompanied by alterations in photosystem II (PSII) activities (Krause and Weis, 1991).

Plants exposed to high levels of irradiance experience a reduction in the quantum efficiency of PSII and consequent changes in the directing of photochemical energy by means of NPQ (Castro et al., 1995; DemmigAdams et al., 1996; Santos Jr. et al., 2006; Gonçalves et al., 2007). Some species under this condition may present increased photosynthetic assimilation (Lichtenthaler and Burkart, 1999) and higher levels of carotenoids, which aid in the protection against photoinhibition (DemmigAdams et al., 1989).

According to Baker (1993), plants subjected to moderate water stress do not exhibit decreased quantum yields of PSII. However, under severe stress conditions, inhibitory effects generally occur, characterized by significant drops in quantum yield. The effect of the water deficit combined with the high rates of irradiance can lead to a significant reduction in photosynthetic assimilation and $E$ as a result of stomatal closing (Prado et al., 2004).

The Atlantic Forest is one of the global biodiversity hotspots (Myers et al., 2000). While the state of Rio de Janeiro, Brazil, maintains $16.7 \%$ of its original coverage of Atlantic Forest (SOS Mata Atlântica, 2001), a large portion of this remaining area is distributed in isolated fragments located in hilly regions and mountain ranges with few forested areas in the low-lying regions. By the beginning of the $21^{\text {st }}$ Century, Brazil had assumed the ranking as the sixth country in the world in terms of area occupied by monocultures of exotic tree species, such as Eucalyptus and Pinus, that totaled 5 million ha (Bacha and Barros, 2004).

Despite the expectation that the cultivation of such monocultures will continue to expand as a result of increased demands for energy and wood (Fonseca et al., 2009), there have been efforts to discourage the presence of exotic species from protected areas, such as the União Biological Reserve (REBIO União), at Rio de Janeiro, where the process of natural regeneration of understory is occurring in abandoned plantations of eucalyptus (Corymbia citriodora). In these understory, Xylopia sericea A. St.-Hil. (Annonaceae) and Siparuna guianensis Aubl. (Siparunaceae) - both in the initial phase of ecological succession - are among the species with the highest value of importance (Evaristo et al., 2011) and are also common in the forest border areas of the REBIO União. In accordance with the management plans of the REBIO União, the removal of eucalyptus trees has been initiated, a practice that has promoted the appearance of forest clearings and has exposed the understory to new microclimatic conditions. Within this context the ecophysiological characteristics of $X$. sericea and $S$. guianensis were evaluated in three forest areas with distinct light intensity conditions (forest understory, eucalyptus understory, and exposed understory in eucalyptus plantations) and water availability (the rainy and dry seasons), in order to answer the following questions: (1) do the plants still undergo photoinhibition 1 year after the clearing of tree canopies? (2) do the species present different photosynthetic responses as a result of environment? (3) is there seasonal variation in the photosynthetic capacities of the species in these three environments?

Such information will be useful for management plans for abandoned monocultures of tree species and will aid in the evaluation of the use potential of these species in the ecological restoration of degraded areas in tropical climates.

\section{MATERIAL AND METHODS}

Study area, plant material and sampling period: REBIO União ( $22^{\circ} 27^{\prime} 30^{\prime \prime} \mathrm{S}$ and $42^{\circ} 02^{\prime} 14^{\prime \prime} \mathrm{W}$ ) occupies an area of 2,550 ha, with approximately 2,200 ha of Atlantic Forest and 220 ha of eucalyptus plantations (C. citriodora). The climate in the region is tropical humid, with an average annual temperature of $25^{\circ} \mathrm{C}$ and rainfall of approximately $1,920 \mathrm{~mm}$ year ${ }^{-1}$, with $85 \%$ of the rainfall concentrated between October and April (Figure 1). According to the IBGE (1992), the vegetation has lowland and submontane formations and is classified as Dense Tropical Rainforest. According to Miranda et al. (2007) the soil of the plantations is dystrophic red-yellow podzolic. 


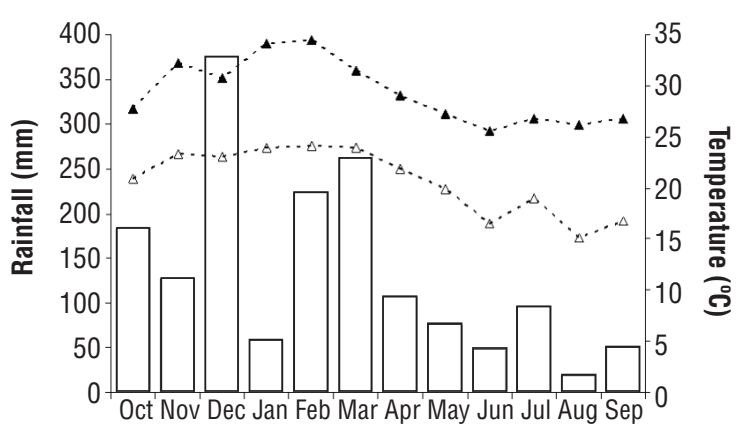

Figure 1. Meteorological data recorded between October 2009 and September 2010 with an automatic weather station (Davis, GroWeather, EUA) in the REBIO União, Brazil. Precipitation: $\Delta$ minimum temperature; $\boldsymbol{\Delta}$ maximum temperature.

Individuals of $X$. sericea (1.5 to $2.0 \mathrm{~m}$ in height) and $S$. guianensis (1.5 to $2.5 \mathrm{~m}$ in height) were selected in three environments with differing lighting and tree canopy conditions in this reserve:

1. Forest Understory (FU): understory on the border of secondary forest. Area with highest species richness and dense canopy formed by native tree species; understory composed principally of bushes, small trees, and plants. This environment presents the lowest light intensity;

2. Eucalyptus Understory (ECU): understory of the eucalyptus (C. citriodora) plantation of 41 years that has received no silvicultural intervention for 13 years. Canopy basically composed of eucalyptus trees. The floristic diversity of this understory is low, with $X$. sericea and $S$. guianensis comprising the most common species (Evaristo et al., 2011). Among the environments, it presents an intermediary level of light intensity;

3. Exposed Understory (EXU): understory of the eucalyptus (C. citriodora) plantation with 15-year-old trees that were removed 1 year before execution of the present study. The understory has thus been exposed to full sunlight since then, making it the environment with the highest degree of light intensity.

Six individuals of each species were analyzed in both the FU and EXU, and nine individuals were selected in the ECU. Two data collections were performed in the rainy season (November 2009 and February 2010) and two collections were performed in the dry season (July and
September of 2010). Thus, a total of 12 measurements on FU and EXU and 18 measurements on ECU were carried out for both seasons for the photosynthetic analyses, as described below.

Gas exchange: $A\left(\mu \mathrm{mol} \mathrm{CO} \mathrm{m}^{-2} \mathrm{~s}^{-1}\right), C_{\mathrm{i}},\left(\mu \mathrm{mol} \mathrm{mol}{ }^{-1}\right)$, $g_{\mathrm{s}}\left(\mathrm{mol} \mathrm{H}_{2} \mathrm{O} \mathrm{m}^{-2} \mathrm{~s}^{-1}\right)$, and $E\left(\mathrm{mmolH}_{2} \mathrm{O} \mathrm{m}^{-2} \mathrm{~s}^{-1}\right)$ were determined using a portable, closed system infrared gas analyzer (Ciras-2, PP System, UK). Measurements were performed between $0800 \mathrm{~h}$ and $1030 \mathrm{~h}$ (period corresponding to the maximum $g_{s}$ ), used with a clamp-on leaf cuvette that exposed $170 \mathrm{~mm}^{2}$ of leaf area. The saturating lights for both species were determined by the response curve of photosynthesis to light; they were of $700 \mu \mathrm{mol} \mathrm{m}^{-2} \mathrm{~s}^{-1}$ for $X$. sericea and $1,100 \mu \mathrm{mol} \mathrm{m} \mathrm{m}^{-2} \mathrm{~s}^{-1}$ for $S$. guianensis. The leaf chamber conditions were: $380 \mu \mathrm{mol} \mathrm{mol}{ }^{-1} \mathrm{CO}_{2}, 28 \pm 3^{\circ} \mathrm{C}$, and $70 \%$ humidity. The IWUE $\left(\mu \mathrm{mol} \mathrm{CO} / \mathrm{mol}^{-1} \mathrm{H}_{2} \mathrm{O}\right)$ was calculated by $\mathrm{A} / g_{\mathrm{s}}$ ratio. Each measurement was carried out on two newly matured leaves per plant and was repeated on each plant for each site.

Chlorophyll a fluorescence: These measurements were carried out at between 1100 and $1200 \mathrm{~h}$ using a pulse amplitude modulation fluorimeter (FMS 2, Hansatech Instruments Ltd., Norfolk, UK). Prior to measurements, intact and healthy leaves were dark adapted using the leaf-clips for $30 \mathrm{~min}$ and then exposing the dark-acclimated leaf surface to modulated irradiance (measuring beam of weak far-red irradiance, approximately $6 \mu \mathrm{mol} \mathrm{m} \mathrm{m}^{-2} \mathrm{~s}^{-1}$ at $660 \mathrm{~nm})$ to obtain the minimum fluorescence yield $\left(F_{0}\right)$ when all PSII reaction centers are open. A saturating white irradiance pulse of 0.8-second duration and intensity of $6,000 \mu \mathrm{mol} \mathrm{m}{ }^{-2} \mathrm{~s}^{-1}$ was then applied to temporarily close all photosystem reaction centers to determine the maximum fluorescence yield $\left(F_{\mathrm{m}}\right)$ of the dark-adapted sample. The samples were then illuminated for 30 seconds with actinic irradiance $\left(300 \mu \mathrm{mol} \mathrm{m}^{-2} \mathrm{~s}^{-1}\right)$. After the illumination (when the fluorescence yield reached a stable and low steady-state level, $\left.F_{\mathrm{s}}\right)$, the maximal fluorescence yield $\left(F_{\mathrm{m}}{ }^{\prime}\right)$ was determined by applying a saturating white irradiance pulse for 0.8 seconds. Then the actinic irradiance was turned off and a far-red illumination was quickly turned on to obtain complete re-oxidation of the primary electron acceptor of PSII to determine the minimal fluorescence yield $\left(F_{0}^{\prime}\right)$ when all PS II reaction centers are open in steady state irradiance. Lightadapted variable fluorescence $(\Delta F)$ was obtained as $\Delta F=$ $F_{\mathrm{m}}{ }^{\prime}-F_{\mathrm{s}}$. The following chlorophyll a fluorescence emission parameters were recorded: $F_{0}$ (minimum fluorescence), $F_{\mathrm{m}}$ (maximum fluorescence), $F_{v} / F_{\mathrm{m}}$ (maximum quantum yield of PSII), $\Delta F / F_{\mathrm{m}}$ ' (effective quantum yield of $\mathrm{PSII}$ ), qP (coefficient of photochemical quenching of fluorescence), and NPQ (non-photochemical quenching of fluorescence). All procedures were adapted from Genty et al. (1989) and Van 
Kooten and Snel (1990). $\Delta F / F_{m}$ ' was used to estimate the apparent ETR, according to Bilger et al. (1995). The ratio of fluorescence yields for open and closed states $\left(F_{\mathrm{m}} / F_{0}\right)$ were calculated. Each measurement was carried out on two newly matured leaves per plant and was repeated on each plant for each site.

Photosynthetic pigment contents: Three discs with $63.6 \mathrm{~mm}^{2}$ each were taken from the same leaves analyzed for gas exchange and chlorophyll a fluorescence from the FU, ECU, and EXU sites. Three discs were sliced and placed in plastic tubes in the dark with a liquid containing $5 \mathrm{~mL}$ of DMSO. After 5 days, the extract was analyzed in a spectrophotometer at wavelengths of 480,649 , and $665 \mathrm{~nm}$. The photosynthetic pigments were quantified according to Wellburn (1994) for chlorophyll a, chlorophyll $b$, and carotenoids. The total chlorophyll, chlorophyll $a / b$, and total chlorophyll/carotenoids ratios were calculated. All the laboratory procedures were carried out in a low light environment. The values were expressed in $\mathrm{nmol} \mathrm{mm}^{-2}$.

Statistical analysis: A descriptive analysis of data was made and the normality and homogeneity of variances were tested. The data of gas exchange, chlorophyll a fluorescence, and photosynthetic pigments were analyzed by MANOVA (Zar, 1996). The factors considered were species, site, and season. After that, the means were compared using Tukey's test. Pearson's correlation coefficients ( $r$ ) were calculated between the $A$ and $g_{s}$ (Zar, 1996).

\section{RESULTS}

Gas exchange: The MANOVA results (Table 1) indicated that $C_{\mathrm{i}}$ and IWUE exhibited interaction between two factors (season versus site), while $A, E$, and $g_{s}$ showed interaction of three factors (season versus site versus species).

In both seasons, for $X$. sericea the values of $A$ were lower in the FU when compared with the ECU, while the values of the EXU did not differ from the other environments (Figure 2A). Comparing the different environments, it is possible to verify that a standard similar to that observed for $A$ was only verified for IWUE in the dry season (Figure $2 \mathrm{E}$ ). In the rainy season, the $X$. sericea plants of the ECU presented higher averages of $C_{\mathrm{i}}$, $E$, and $g_{\mathrm{s}}$ (Figures $2 \mathrm{~B}, \mathrm{C}$, and $D)$, while IWUE was higher in this environment in the dry season (Figure $2 \mathrm{E}$ ). The gas exchange variables of the other environments did not show seasonal differences $(p>0.05)$.

For $S$. guianensis, the $A, E$, and $g_{\mathrm{s}}$ variables were higher in the EXU plants in relation to the other environments during the rainy season (Figures $2 \mathrm{~F}-\mathrm{I}$ ). In the EXU, the seasonal variations were more visually apparent, as plants presented lower values of $A, C, E$, and $g_{\mathrm{s}}$ in the dry period (Figures 2F, G, $\mathrm{H}$ and $\mathrm{I}$ ). In the environment with intermediary conditions (ECU), only $C_{i}$ and $g_{s}$ presented lower values in the dry season (Figures $2 G$ and I). The ECU and EXU plants exhibited higher IWUE values in the dry season (Figure 2J).

When comparing species, it is possible to observe that $S$. guianensis presented higher averages of $A$ (Figures $2 \mathrm{~A}$ and $\mathrm{F}$ ), $E$ (Figures $2 \mathrm{C}$ and $\mathrm{H}$ ), and $g_{\mathrm{s}}$ (Figures $2 \mathrm{D}$ and $\mathrm{I}$ ) in relation to $X$. sericea in the EXU during the rainy period. The IWUE variable was higher in $S$. guianensis in the FU and in the EXU during the dry period (Figures 2E and J). $X$. sericea exhibited a higher

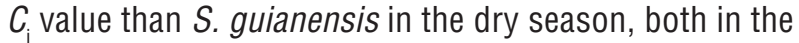
FU and the EXU (Figures 2B and G).

Table 1. Results of multivariate analysis of variance (MANOVA) performed for the gas exchange of the species in REBIO União, Brazil.

\begin{tabular}{|c|c|c|c|c|c|c|c|c|c|c|}
\hline \multirow{2}{*}{ Effect } & \multicolumn{2}{|c|}{$A$} & \multicolumn{2}{|c|}{$C_{i}$} & \multicolumn{2}{|c|}{$E$} & \multicolumn{2}{|c|}{$g_{s}$} & \multicolumn{2}{|c|}{ IWUE } \\
\hline & $F$ & $p$-value & $F$ & p-value & $F$ & p-value & $F$ & $p$-value & $F$ & $p$-value \\
\hline Species & 9.21 & $0.0028^{*}$ & 30.99 & $0.0000^{*}$ & 1.23 & 0.2683 & 0.64 & 0.4262 & 27.66 & $0.0000^{*}$ \\
\hline Season & 7.35 & $0.0075^{\star}$ & 54.15 & $0.0000^{*}$ & 32.25 & $0.0000^{*}$ & 60.28 & $0.0000^{\star}$ & 55.91 & $0.0000^{*}$ \\
\hline Site & 14.78 & $0.0000^{*}$ & 2.07 & 0.1301 & 7.72 & $0.0006^{*}$ & 6.92 & $0.0013^{*}$ & 1.70 & 0.1862 \\
\hline Species*Season & 4.06 & $0.0455^{\star}$ & 8.04 & $0.0052^{*}$ & 11.09 & $0.0011^{*}$ & 8.93 & $0.0033^{\star}$ & 10.55 & $0.0014^{*}$ \\
\hline Species*Site & 13.12 & $0.0000^{*}$ & 2.73 & 0.0687 & 9.35 & $0.0002^{*}$ & 6.38 & $0.0022^{*}$ & 1.50 & 0.2265 \\
\hline Season ${ }^{\star}$ Site & 7.71 & $0.0006^{*}$ & 5.46 & $0.0051^{*}$ & 4.03 & $0.0197^{\star}$ & 14.66 & $0.0000^{*}$ & 7.31 & $0.0009^{*}$ \\
\hline Species*Season*Site & 3.08 & $0.0486^{*}$ & 1.43 & 0.2415 & 5.87 & $0.0035^{\star}$ & 5.64 & $0.0043^{\star}$ & 2.53 & 0.0828 \\
\hline
\end{tabular}

${ }^{*}$ Significant difference $(p \leq 0.05)$

Species: Xylopia sericea and Siparuna guianensis; seasons: rainy and dry; sites: FU: Forest Understory $(n=12)$; ECU: Eucalyptus Understory $(\mathrm{n}=18)$; EXU: Exposed Understory $(\mathrm{n}=12)$.

$A$ : net photosynthetic rate; $C_{i}$ : internal $\mathrm{CO}_{2}$ concentration; $E$ : transpiration; $g_{\mathrm{s}}$ : stomatal conductance; IWUE: intrinsic water-use efficient. 
A

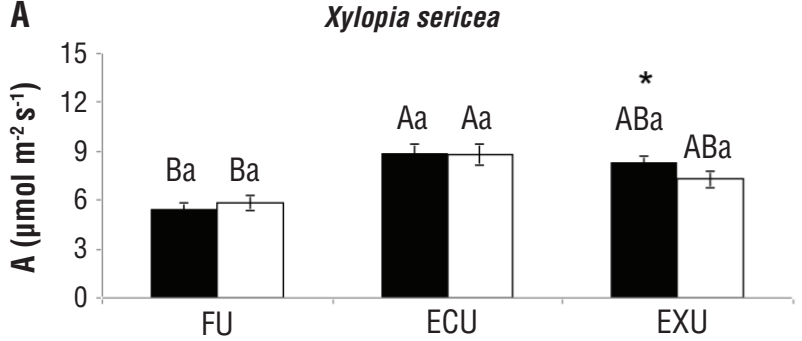

B 350

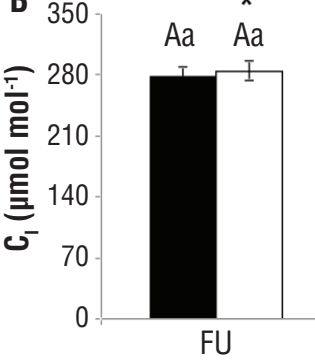

C

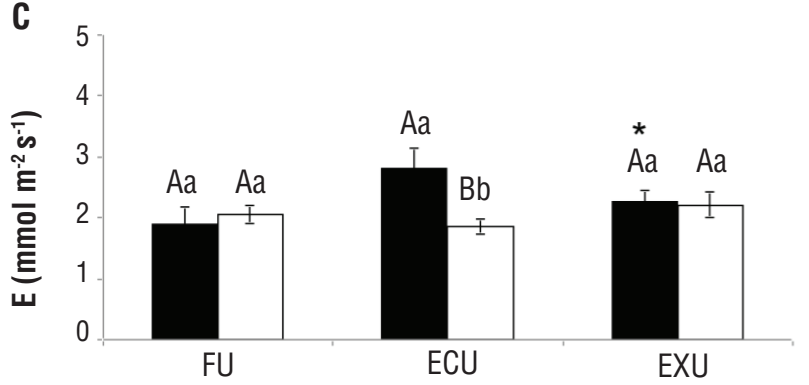

D 0.5

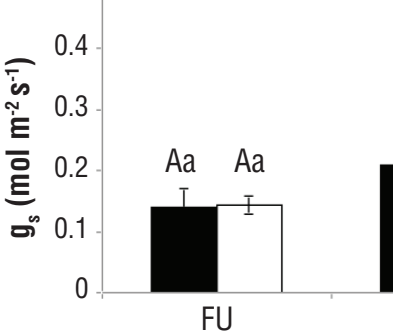

E 150

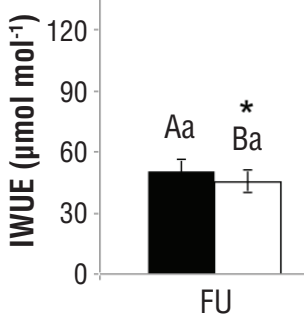

Aa

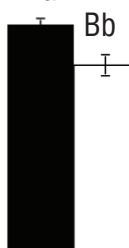

ECU

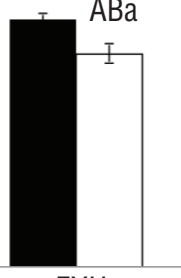

EXU

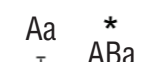

$\mathbf{F}$

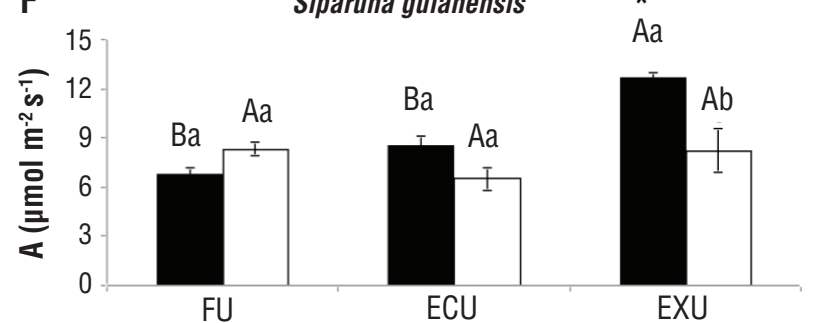

G 350

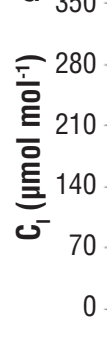

H

H 5

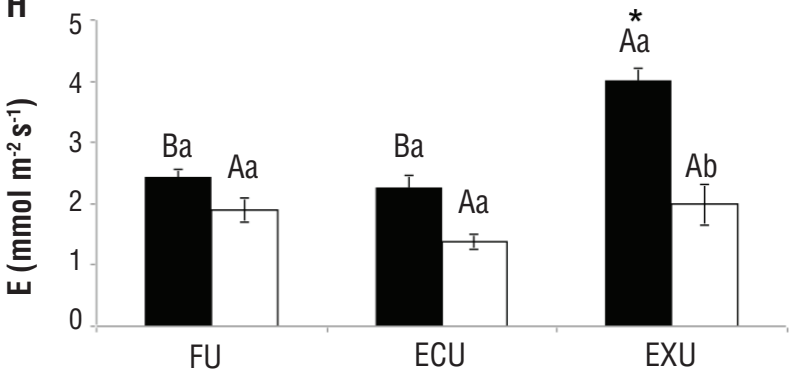

I 0.5
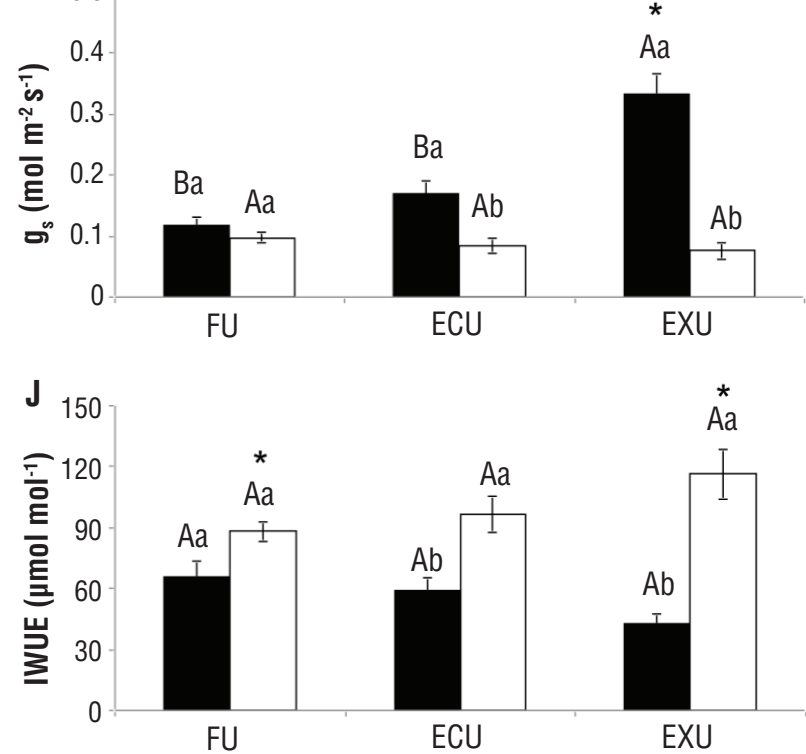

Figure 2. Gas exchange of Xylopia sericea (left column) and Siparuna guianensis (right column) in REBIO União, Brazil. (A and F) Net photosynthetic rate $(A)$, (B and $\mathrm{G})$ internal $\mathrm{CO}_{2}$ concentration $\left(C_{\mathrm{i}}\right),(\mathrm{C}$ and $\mathrm{H})$ transpiration $(E)$, (D and I) stomatal conductance $\left(g_{\mathrm{s}}\right)$, and $(\mathrm{E}$ and J) intrinsic water-use efficient (IWUE). FU: Forest Understory ( $n=12)$; ECU: Eucalyptus Understory ( $n=18)$; EXU: Exposed Understory $(n=12)$. Rainy season ( $\bullet)$; Dry season ( $\square)$. Upper case letters compare the three environments in the same season. Lower case letters compare the two seasons in the same environment. Asterisks $\left({ }^{*}\right)$ indicate differences among species of the same environment and season. The data represent mean \pm standard error. Distinct letters indicate significant differences $(p \leq 0.05)$. 
The correlation between $A$ and $g_{\mathrm{s}}$ (Table 2) was tested to determine how much of the carbon assimilation is dependent on the stomatal opening. There was a significant positive correlation between these parameters in the dry period for $S$. guianensis in all three environments and for $X$. sericea in the ECU and in the EXU. In the rainy season only $X$. sericea presented this significant correlation in the FU and the ECU (Table 2).

Chlorophyll a fluorescence: The MANOVA results (Table 3) indicated that the parameters $\Delta F / F_{\mathrm{m}}{ }^{\prime}$ and $\mathrm{qP}$ showed interaction between three factors (season versus site versus species). The $F_{\sqrt{ }} / F_{\mathrm{m}}$ and $F_{\mathrm{m}} / F_{0}$ ratios and the $\mathrm{NPQ}$ showed interaction for season versus site, while ETR exhibited interaction for the species versus site.

For the $X$. sericea of the EXU, the lowest values of $\Delta F / F_{\mathrm{m}}$ ' were registered in the dry season and lower values of $F_{v} / F_{m}$ and $F_{m} / F_{0}$ were registered in both seasons in relation to the other environments (Table 4). During the dry season qP presented a lower average in the FU plants. The NPQ indicated that there was higher dissipation in the FU and EXU plants in $X$. sericea when compared to the ECU plants, during the rainy period. In the dry season, however, this parameter was higher in the EXU plants.

With respect to seasonal variation, $X$. sericea only exhibited significant differences in $F_{v} / F_{\mathrm{m}}$ and $F_{\mathrm{m}} / F_{0}$ values in the EXU plants, with the values for these variables being lower in the dry season. In the ECU plants, a higher average $\mathrm{qP}$ was registered in the dry period in relation to the rainy one, while the effective quantum yield $\left(\triangle F / F_{\mathrm{m}}{ }^{\prime}\right)$ and the ETR were higher in the EXU plants in the rainy period when compared with the dry one (Table 4).

Table 2. Correlation between net photosynthetic rate $(A)$ and stomatal conductance $\left(g_{s}\right)$ of Xylopia sericea and Siparuna guianensis in REBIO União, Brazil

\begin{tabular}{|c|c|c|c|c|c|c|}
\hline & \multicolumn{2}{|c|}{ FU } & \multicolumn{2}{|c|}{ ECU } & \multicolumn{2}{|c|}{ EXU } \\
\hline & $r$ & $\mathrm{p}$-value & $r$ & $\mathrm{p}$-value & $r$ & $\mathrm{p}$-value \\
\hline \multicolumn{7}{|c|}{ Xylopia sericea } \\
\hline Rainy & 0.90 & $0.0001^{*}$ & 0.83 & $0.0001^{*}$ & 0.51 & 0.0906 \\
\hline Dry & -0.01 & 0.9753 & 0.67 & $0.0022^{*}$ & 0.61 & $0.0334^{*}$ \\
\hline \multicolumn{7}{|c|}{ Siparuna guianensis } \\
\hline Rainy & 0.34 & 0.2836 & 0.43 & 0.0759 & 0.13 & 0.6942 \\
\hline Dry & 0.60 & $0.0396^{*}$ & 0.79 & $0.0001^{\star}$ & 0.97 & $0.0001^{*}$ \\
\hline
\end{tabular}

*Positive correlation.

FU: Forest Understory ( $n=12)$; ECU: Eucalyptus Understory ( $n=18)$; EXU: Exposed Understory $(n=12)$.

Table 3. Results of multivariate analysis of variance (MANOVA) performed for the chlorophyll fluorescence a parameters of the species in REBIO União, Brazil.

\begin{tabular}{|c|c|c|c|c|c|c|c|c|c|c|c|c|}
\hline \multirow{2}{*}{ Effect } & \multicolumn{2}{|c|}{$\mathrm{F}_{\mathrm{v}} / \mathrm{F}_{\mathrm{m}}$} & \multicolumn{2}{|c|}{$\mathrm{F}_{\mathrm{m}} / \mathrm{F}_{0}$} & \multicolumn{2}{|c|}{$\Delta F / F_{m}{ }^{\prime}$} & \multicolumn{2}{|c|}{ ETR } & \multicolumn{2}{|c|}{$\mathrm{qP}$} & \multicolumn{2}{|c|}{ NPQ } \\
\hline & $F$ & p-value & $F$ & $p$-value & $F$ & p-value & $F$ & p-value & $\mathbf{F}$ & p-value & $F$ & $\mathrm{p}$-value \\
\hline Species & 11.53 & $0.0009^{\star}$ & 30.59 & $0.0000^{*}$ & 0.54 & 0.4616 & 58.39 & $0.0000^{\star}$ & 1.28 & 0.2601 & 25.34 & $0.0000^{*}$ \\
\hline Season & 51.19 & $0.0000^{*}$ & 39.51 & $0.0000^{*}$ & 31.46 & $0.0000^{\star}$ & 10.97 & $0.0012^{*}$ & 0.50 & 0.4794 & 42.96 & $0.0000^{*}$ \\
\hline Site & 137.74 & $0.0000^{*}$ & 258.84 & $0.0000^{*}$ & 26.25 & $0.0000^{\star}$ & 19.86 & $0.0000^{*}$ & 25.13 & $0.0000^{*}$ & 16.34 & $0.0000^{*}$ \\
\hline Species *Season & 0.39 & 0.5334 & 0.04 & 0.8473 & 3.91 & $0.0499^{\star}$ & 0.01 & 0.9533 & 5.34 & $0.0222^{*}$ & 0.01 & 0.9555 \\
\hline Species ${ }^{\star}$ Site & 1.65 & 0.1958 & 0.38 & 0.6813 & 1.33 & 0.2687 & 7.56 & $0.0007^{\star}$ & 1.42 & 0.2452 & 8.80 & $0.0002^{*}$ \\
\hline Season*Site & 46.33 & $0.0000^{*}$ & 36.96 & $0.0000^{*}$ & 31.94 & $0.0000^{*}$ & 2.42 & 0.0922 & 7.66 & $0.0007^{*}$ & 5.08 & $0.0073^{*}$ \\
\hline Species*Season*Site & 0.52 & 0.5985 & 0.07 & 0.9325 & 4.34 & $0.0146^{\star}$ & 1.20 & 0.3052 & 8.70 & $0.0003^{*}$ & 0.67 & 0.5129 \\
\hline
\end{tabular}

*Significant difference $(p \leq 0.05)$

$F_{\mathrm{v}} / F_{\mathrm{m}}$ : maximum quantum yield of PSII; $F_{\mathrm{m}} / F_{\mathrm{o}}$ : ratio of fluorescence yields for open and closed states; $\triangle F / F_{\mathrm{m}}$; effective quantum yield of PSII; ETR: apparent electron transport rate; $\mathrm{qP}$ : coefficient of photochemical quenching of fluorescence; NPQ, nonphotochemical quenching of fluorescence. Species: Xylopia sericea and Siparuna guianensis; seasons: rainy and dry; sites: FU: Forest Understory ( $n=12)$; ECU: Eucalyptus Understory ( $n=18)$; EXU: Exposed Understory $(n=12)$. 
Table 4. Chlorophyll a fluorescence parameters of Xylopia sericea and Siparuna guianensis in REBIO União, Brazil.

\begin{tabular}{|c|c|c|c|c|c|c|c|}
\hline \multirow{2}{*}{ Sp. } & \multirow{2}{*}{ Env. } & \multicolumn{6}{|c|}{ Chlorophyll a Fluorescence Parameters } \\
\hline & & $F_{v} / F_{m}$ & $\mathrm{~F}_{\mathrm{m}} / \mathrm{F}_{0}$ & $\Delta F / F_{m}{ }^{\prime}$ & ETR & $\mathrm{qP}$ & NPQ \\
\hline \multirow{9}{*}{ 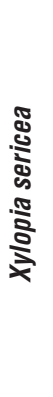 } & FU & & & & & & \\
\hline & Rainy & $0.813 \pm 0.004 \mathrm{Aa}$ & $5.4 \pm 0.1 \mathrm{Aa}$ & $0.64 \pm 0.01 \mathrm{Aa}$ & $80.5 \pm 1.8 \mathrm{Aa}$ & $0.86 \pm 0.01 \mathrm{Aa}$ & $0.30 \pm 0.04 \mathrm{Aa}$ \\
\hline & Dry & $0.815 \pm 0.005 \mathrm{Aa}$ & $5.5 \pm 0.1 \mathrm{Aa}$ & $0.63 \pm 0.02 \mathrm{Aa}$ & $79.7 \pm 1.9 \mathrm{Aa}$ & $0.85 \pm 0.01 \mathrm{Ba}$ & $0.38 \pm 0.06 \mathrm{Ba}$ \\
\hline & ECU & & & & & & \\
\hline & Rainy & $0.811 \pm 0.004 \mathrm{Aa}$ & $5.3 \pm 0.1 \mathrm{Aa}$ & $0.65 \pm 0.01 \mathrm{Aa}$ & $82.0 \pm 1.2 \mathrm{Aa}$ & $0.86 \pm 0.01 \mathrm{Ab}$ & $0.16 \pm 0.01 \mathrm{Ba}$ \\
\hline & Dry & $0.808 \pm 0.007 \mathrm{Aa}$ & $5.3 \pm 0.2 \mathrm{Aa}$ & $0.67 \pm 0.01 \mathrm{Aa}$ & $84.5 \pm 1.2 \mathrm{Aa}$ & $0.90 \pm 0.01 \mathrm{Aa}$ & $0.27 \pm 0.03 \mathrm{Ba}$ \\
\hline & EXU & & & & & & \\
\hline & Rainy & $0.759 \pm 0.007 \mathrm{Ba}$ & $4.2 \pm 0.1 \mathrm{Ba}$ & $0.63 \pm 0.01 \mathrm{Aa}$ & $79.3 \pm 1.2 \mathrm{Aa}$ & $0.90 \pm 0.01 \mathrm{Aa}$ & $0.35 \pm 0.05 \mathrm{Ab}$ \\
\hline & Dry & $0.614 \pm 0.023 \mathrm{Bb}$ & $2.8 \pm 0.1 \mathrm{Bb}$ & $0.53 \pm 0.02 \mathrm{Bb}$ & $66.7 \pm 2.7 \mathrm{Bb}$ & $0.90 \pm 0.01 \mathrm{Aa}$ & $0.59 \pm 0.03 \mathrm{Aa}$ \\
\hline \multirow{9}{*}{ 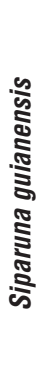 } & FU & & & & & & \\
\hline & Rainy & $0.828 \pm 0.002 \mathrm{Aa}$ & $5.8 \pm 0.1 \mathrm{Aa}$ & $0.60 \pm 0.01 \mathrm{Ba}$ & $76.2 \pm 1.4 \mathrm{Ba}$ & $0.81 \pm 0.02 \mathrm{Ca}$ & $0.44 \pm 0.05 \mathrm{Aa}$ \\
\hline & Dry & $0.828 \pm 0.002 \mathrm{Aa}$ & $5.8 \pm 0.1 \mathrm{Aa}$ & $0.63 \pm 0.01 \mathrm{Aa}$ & $80.0 \pm 1.1 \mathrm{Aa}$ & $0.85 \pm 0.01 \mathrm{Aa}$ & $0.47 \pm 0.05 \mathrm{Ba}$ \\
\hline & ECU & & & & & & \\
\hline & Rainy & $0.824 \pm 0.002 \mathrm{Aa}$ & $5.7 \pm 0.1 \mathrm{Aa}$ & $0.67 \pm 0.01 \mathrm{ABa}$ & $83.8 \pm 0.8 \mathrm{ABa}$ & $0.89 \pm 0.01 \mathrm{Ba}$ & $0.34 \pm 0.02 \mathrm{Ab}$ \\
\hline & Dry & $0.820 \pm 0.004 \mathrm{Aa}$ & $5.6 \pm 0.1 \mathrm{Aa}$ & $0.63 \pm 0.01 \mathrm{Aa}$ & $79.2 \pm 1.1 \mathrm{Aa}$ & $0.87 \pm 0.01 \mathrm{Aa}$ & $0.51 \pm 0.04 \mathrm{ABa}$ \\
\hline & EXU & & & & & & \\
\hline & Rainy & $0.784 \pm 0.074 \mathrm{Aa}$ & $4.6 \pm 0.1 \mathrm{Ba}$ & $0.68 \pm 0.01 \mathrm{Aa}$ & $85.6 \pm 1.0 \mathrm{Aa}$ & $0.94 \pm 0.01 \mathrm{Aa}$ & $0.35 \pm 0.03 \mathrm{Ab}$ \\
\hline & Dry & $0.665 \pm 0.068 \mathrm{Bb}$ & $3.3 \pm 0.2 \mathrm{Bb}$ & $0.51 \pm 0.03 \mathrm{Bb}$ & $63.7 \pm 4.1 \mathrm{Bb}$ & $0.87 \pm 0.01 \mathrm{Ab}$ & $0.58 \pm 0.05 \mathrm{Aa}$ \\
\hline
\end{tabular}

Upper case letters compare the three environments in the same season for each species. Lower case letters compare the two seasons in the same environment. Distinct letters indicate significant differences $(p \leq 0.05)$. Data represent mean \pm standard error.

FU: Forest Understory ( $n=12)$; ECU: Eucalyptus Understory ( $n=18)$; EXU: Exposed Understory $(n=12)$.

Sp.: species; Env.: environment; $F_{\sqrt{ }} / F_{\mathrm{m}}$ : maximum quantum yield of $\mathrm{PSII} ; F_{\mathrm{m}} / F_{\mathrm{o}}$ : ratio of fluorescence yields for open and closed states; $\Delta F / F_{\mathrm{m}}$ : effective quantum yield of PSII; ETR: apparent electron transport rate; qP: coefficient of photochemical quenching of fluorescence; NPQ: nonphotochemical quenching of fluorescence.

Siparuna guianensis exhibited a lower $F_{\mathrm{m}} / F_{0}$ average in the EXU plants in relation to the plants in the other environments, while $F_{v} / F_{m}, \Delta F / F_{m}$, and ETR only responded in this manner in the dry season (Table 4). In the rainy season, $\Delta F / F_{\mathrm{m}}$, and ETR exhibited intermediary values in the ECU, being higher in the EXU plants in relation to those in the FU. S. guianensis, in the EXU, demonstrated higher $q P$ during the rainy season. There was higher NPQ in the EXU plants in comparison with those in the FU, with intermediary values in the ECU plants in the dry season (Table 4).

When comparing $S$. guianensis values between the rainy and dry seasons significant differences were only verified for $F_{v} / F_{\mathrm{m}}, F_{\mathrm{m}} / F_{0,} \Delta F / F_{\mathrm{m}}{ }^{\prime}, E T R$, and $\mathrm{qP}$ in the EXU plants, with the highest averages registered during the rainy season. The NPQ was higher in the dry season in the ECU and EXU plants (Table 4).

In the EXU plants, the $F_{\mathrm{v}} / F_{\mathrm{m}}$ values were lower than 0.78 in both species and seasons. Comparisons of the species reveal no significant difference between $X$. sericea and $S$. guianensis for any of the chlorophyll a fluorescence variables (Table 4).

Photosynthetic pigments: The MANOVA results (Table 5) indicated that chlorophyll $a$, chlorophyll $a / b$ ratio, total chlorophyll/carotenoids ratio, and total chlorophyll showed interaction between three factors (season versus site versus species). The carotenoids showed seasonal factors interact with the site, while chlorophyll $b$ showed interaction with the factors species and site.

The plants of both species presented lower levels of chlorophylls and total chlorophyll/carotenoids ratios in the EXU plants during both seasons of the year (Table 6). Lower values of chlorophyll a, carotenoids, and total chlorophyll were observed in the rainy season as compared to the dry season in the ECU plants. In $S$. guianensis in the EXU levels of carotenoids were higher during the dry period in relation to the rainy period. In species comparisons, plants in the EXU during the dry season presented pigment levels that were superior in S. guianensis (Table 6). 
Table 5. Results of multivariate analysis of variance (MANOVA) performed for the content of photosynthetic pigments of the species in REBIO União, (RJ), Brazil.

\begin{tabular}{|c|c|c|c|c|c|c|c|c|c|c|c|c|}
\hline \multirow{2}{*}{ Effect } & \multicolumn{2}{|c|}{$\mathrm{Chl}$ a } & \multicolumn{2}{|c|}{ Chl b } & \multicolumn{2}{|c|}{$C_{x+c}$} & \multicolumn{2}{|c|}{$\mathrm{Chl} \mathrm{a} / \mathrm{b}$} & \multicolumn{2}{|c|}{$\mathrm{Chl}_{\text {Total }} / \mathbf{C}_{\mathrm{x}+\mathrm{c}}$} & \multicolumn{2}{|c|}{$\mathrm{Chl}_{\text {Total }}$} \\
\hline & $\mathbf{F}$ & $p$-value & $F$ & $p$-value & $\mathrm{F}$ & $p$-value & $\mathrm{F}$ & $\mathrm{p}$-value & $\mathbf{F}$ & $p$-value & $F$ & p-value \\
\hline Species & 40.35 & $0.0000^{*}$ & 23.81 & $0.0000^{*}$ & 4.37 & $0.0383^{*}$ & 0.00 & 0.9807 & 32.45 & $0.0000^{\star}$ & 33.25 & $0.0000^{\star}$ \\
\hline Season & 25.12 & $0.0000^{*}$ & 0.82 & 0.3664 & 17.84 & $0.0000^{*}$ & 41.10 & $0.0000^{*}$ & 5.51 & $0.0202^{*}$ & 17.02 & $0.0001^{*}$ \\
\hline Site & 74.12 & $0.0000^{*}$ & 30.22 & $0.0000^{*}$ & 8.87 & $0.0002^{*}$ & 8.70 & $0.0003^{*}$ & 109.74 & $0.0000^{*}$ & 52.59 & $0.0000^{*}$ \\
\hline Species ${ }^{\star}$ Season & 9.08 & $0.0030^{\star}$ & 12.86 & $0.0005^{\star}$ & 6.33 & $0.0129^{*}$ & 4.45 & $0.0366^{*}$ & 1.63 & 0.2035 & 11.03 & $0.0011^{*}$ \\
\hline Species*Site & 7.33 & $0.0009^{*}$ & 7.27 & $0.0010^{*}$ & 2.59 & 0.0782 & 0.95 & 0.3884 & 7.76 & $0.0006^{\star}$ & 7.19 & $0.0010^{*}$ \\
\hline Season ${ }^{\star}$ Site & 5.19 & $0.0066^{\star}$ & 0.20 & 0.8227 & 10.13 & $0.0001^{*}$ & 4.36 & $0.0144^{\star}$ & 5.54 & $0.0048^{\star}$ & 4.27 & $0.0156^{*}$ \\
\hline Species*Season*Site & 5.48 & $0.0050^{*}$ & 0.60 & 0.5509 & 1.95 & 0.1456 & 4.31 & $0.0151^{*}$ & 3.48 & $0.0332^{*}$ & 3.70 & $0.0270^{*}$ \\
\hline
\end{tabular}

${ }^{*}$ Significant difference $(p \leq 0.05)$.

Species: Xylopia sericea and Siparuna guianensis; seasons: rainy and dry; sites: FU: Forest Understory ( $n=12)$; ECU: Eucalyptus Understory ( $n=18)$; EXU: Exposed Understory $(n=12)$.

Chl: chlorophyll; $\mathrm{C}_{x+c}$ : carotenoids.

Table 6. Content of photosynthetic pigments ( $\mathrm{nmol} \mathrm{mm}{ }^{-2}$ ) of Xylopia sericea and Siparuna guianensis in REBIO União (RJ), Brazil.

\begin{tabular}{|c|c|c|c|c|c|c|c|c|}
\hline \multirow{2}{*}{ Sp. } & \multirow{2}{*}{ Env. } & \multicolumn{7}{|c|}{ Photosynthetic Pigments } \\
\hline & & $\mathrm{Chl} \mathrm{a}$ & Chl b & $C_{x+c}$ & $\mathrm{Chl} \mathrm{a} / \mathrm{b}$ & $\mathrm{Chl}_{\text {Total }} / \mathrm{C}_{\mathrm{x}+\mathrm{c}}$ & $\mathrm{ChI}_{\text {Total }}$ & \\
\hline \multirow{9}{*}{ 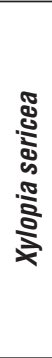 } & FU & & & & & & & \\
\hline & Rainy & $0.31 \pm 0.014 \mathrm{Aa}$ & $0.11 \pm 0.006 \mathrm{Aa}$ & $0.06 \pm 0.003 \mathrm{Aa}$ & $2.9 \pm 0.1 \mathrm{Aa}$ & $7.4 \pm 0.2 \mathrm{Aa}^{*}$ & $0.42 \pm 0.020$ & $\mathrm{Aa}$ \\
\hline & Dry & $0.32 \pm 0.020 \mathrm{Aa}$ & $0.10 \pm 0.007 \mathrm{Aa}$ & $0.06 \pm 0.004 \mathrm{ABa}$ & $3.1 \pm 0.1 \mathrm{ABa}$ & $7.1 \pm 0.1 \mathrm{Aa}$ & $0.42 \pm 0.027$ & $\mathrm{Aa}$ \\
\hline & ECU & & & & & & & \\
\hline & Rainy & $0.29 \pm 0.005 \mathrm{Ab}$ & $0.11 \pm 0.005 \mathrm{Aa}$ & $0.06 \pm 0.001 \mathrm{Ab}$ & $2.7 \pm 0.1 A b^{*}$ & $7.3 \pm 0.2 \mathrm{Aa}$ & $0.40 \pm 0.009$ & $A b$ \\
\hline & Dry & $0.36 \pm 0.015 \mathrm{Aa}$ & $0.11 \pm 0.007 \mathrm{Aa}$ & $0.07 \pm 0.003 \mathrm{Aa}$ & $3.5 \pm 0.1 \mathrm{Aa}$ & $6.5 \pm 0.1 \mathrm{Ab}$ & $0.47 \pm 0.022$ & $\mathrm{Aa}$ \\
\hline & EXU & & & & & & & \\
\hline & Rainy & $0.20 \pm 0.012 \mathrm{Ba}$ & $0.07 \pm 0.002 \mathrm{Ba}$ & $0.06 \pm 0.006 \mathrm{Aa}$ & $2.8 \pm 0.1 \mathrm{Aa}$ & $4.8 \pm 0.3 \mathrm{Ba}$ & $0.27 \pm 0.014$ & $\mathrm{Ba}$ \\
\hline & Dry & $0.17 \pm 0.008 \mathrm{Ba}^{*}$ & $0.06 \pm 0.003 \mathrm{Ba}^{*}$ & $0.05 \pm 0.002 \mathrm{Ba}^{*}$ & $3.0 \pm 0.1 \mathrm{Ba}$ & $4.4 \pm 0.3 \mathrm{Ba}$ & $0.23 \pm 0.010$ & $\mathrm{Ba}^{*}$ \\
\hline \multirow{9}{*}{ 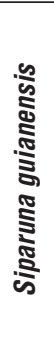 } & FU & & & & & & & \\
\hline & Rainy & $0.31 \pm 0.006 \mathrm{Aa}$ & $0.11 \pm 0.002 \mathrm{Aa}$ & $0.05 \pm 0.002 \mathrm{Aa}$ & $2.9 \pm 0.0 \mathrm{Aa}$ & $8.4 \pm 0.2 \mathrm{Aa}^{*}$ & $0.42 \pm 0.008$ & $\mathrm{ABa}$ \\
\hline & Dry & $0.36 \pm 0.010 \mathrm{Aa}$ & $0.12 \pm 0.006 \mathrm{Aa}$ & $0.06 \pm 0.002 \mathrm{Ba}$ & $3.1 \pm 0.1 \mathrm{Aa}$ & $7.7 \pm 0.2 \mathrm{Aа}$ & $0.48 \pm 0.015$ & $\mathrm{Aa}$ \\
\hline & ECU & & & & & & & \\
\hline & Rainy & $0.33 \pm 0.010 \mathrm{Ab}$ & $0.11 \pm 0.004 \mathrm{Aa}$ & $0.06 \pm 0.002 \mathrm{Ab}$ & $3.1 \pm 0.1 \mathrm{Aa}^{*}$ & $7.3 \pm 0.1 \mathrm{Ba}$ & $0.44 \pm 0.013$ & $A b$ \\
\hline & Dry & $0.39 \pm 0.017 \mathrm{Aa}$ & $0.12 \pm 0.007 \mathrm{Aa}$ & $0.08 \pm 0.004 \mathrm{ABa}$ & $3.3 \pm 0.1 \mathrm{Aa}$ & $6.7 \pm 0.1 \mathrm{Ba}$ & $0.51 \pm 0.023$ & $\mathrm{Aa}$ \\
\hline & EXU & & & & & & & \\
\hline & Rainy & $0.24 \pm 0.009 \mathrm{Ba}$ & $0.09 \pm 0.004 \mathrm{Aa}$ & $0.06 \pm 0.002 \mathrm{Ab}$ & $2.7 \pm 0.1 \mathrm{Aa}$ & $5.4 \pm 0.1 \mathrm{Ca}$ & $0.33 \pm 0.012$ & $\mathrm{Ba}$ \\
\hline & Dry & $0.24 \pm 0.015 \mathrm{Ba}^{*}$ & $0.08 \pm 0.005 \mathrm{Ba}^{*}$ & $0.08 \pm 0.006 \mathrm{Aa}^{*}$ & $2.9 \pm 0.1 \mathrm{Aa}$ & $4.0 \pm 0.2 \mathrm{Cb}$ & $0.32 \pm 0.020$ & $\mathrm{Ba}^{*}$ \\
\hline
\end{tabular}

Upper case letters compare the three environments in the same season for each species; lower case letters compare the two seasons in the same environment; distinct letters indicate significant difference $(p \leq 0.05)$. Data represent mean \pm standard error.

${ }^{*}$ Difference between the species within the same environment and season.

Sp.: species; Env.: environment; Chl: chlorophyll; $C_{x+c}$ : carotenoids; FU: Forest Understory $(n=12)$; ECU: Eucalyptus Understory ( $\left.n=18\right)$; EXU: Exposed Understory $(n=12)$.

\section{DISCUSSION}

The values of the gas exchange variables registered in the present study for $X$. sericea and $S$. guianensis are situated within the parameters observed for other tropical tree species (Baker et al., 1997; Eschenbach et al., 1998; Marenco et al., 2001; Costa and Marenco, 2007; Gonçalves et al., 2009; Silva et al., 2010). The species $X$. sericea and $S$. guianensis exhibited high values of correlation between $A$ and $g_{s}$ in the dry season, suggesting that their stomata respond significantly to the variations in light and water availability. Nevertheless, in the rainy season, only $X$. sericea presented positive correlation between $A$ and $g_{s}$. The absence or low correlation between $A$ and $g_{\mathrm{s}}$ demonstrate that both the $g_{\mathrm{s}}$ and photosynthesis are parameters that respond concomitantly to a series of factors that interact in a coordinated yet highly complex manner (Costa and Marenco, 2007). The high irradiance and low $\mathrm{CO}_{2}$ concentration stimulate the opening of stomata, while the excessive $E$ and low humidity cause 
a reduction in leaf water potential that can lead to the closing of stomata (Hsiao, 1973; Marenco et al., 2006). Because of this, it is common to register an absence or low correlation between $A$ and $g_{s}$ in natural lighting and air humidity conditions.

With respect to the environmental variation, $E$ presented a pattern similar to the responses observed for $g_{s} . X$. sericea, however, did not respond in the same way as $S$. guianensis, demonstrating that the responses to variations in lighting differ between the species. According to Marenco and Lopes (2007), this is justified by the fact that the control of stomatal movement and of $E$ results from the interaction of diverse exogenous factors, such as light, $\mathrm{CO}_{2}$, temperature, and water tension, as well as endogenous ones, such as nutrition and the presence of hormones in the plant.

In $S$. guianensis in the EXU the stomatal closing represented a principal cause of the reduction in the photosynthetic rate and in the $E$ under conditions of water deficit. This reduction resulted in the decreased availability of $\mathrm{CO}_{2}$ in the substomatal chambers. Similar results were reported for young Carapa guianensis plants submitted to the suspension of irrigation (Gonçalves et al., 2009). The reduction of the $E$ and $g_{s}$ in $S$. guianensis resulted in higher intrinsic efficiency in the use of the water (IWUE) during the dry season. These results suggest that, for $S$. guianensis, the lower availability of water was an important stress factor in the plants submitted to higher irradiance (EXU) in the dry season. However, when water was not a limiting factor, a better photosynthetic performance was observed in this species in conditions of higher light intensity. Similar results were reported by Silva et al. (2010) in studies carried out on the pioneer species Byrsonima sericea during the dry and rainy season in the REBIO União.

The decline in the photosynthetic assimilation in $S$. guianensis in the dry season compared with the rainy season in the EXU was accompanied by a decrease in $F_{\sqrt{ }} F_{\mathrm{m}}, F_{\mathrm{m}} / F_{0}$, $\Delta F / F_{\mathrm{m}}{ }^{\prime}, E T R$, and total chlorophyll/carotenoids ratios, as well as an increase in NPQ and carotenoid levels. These results were observed in conjunction with lower carbon assimilation due to the decrease in $g_{s}$. These responses can be seen as an important protective mechanism under conditions of water stress in $S$. guianensis. Similar results were observed by Faria et al. $(1996 ; 1998)$ in studies of the Quercus ilex and Quercus súber species, which emphasized the high degree of coordination between stomatal comportment, photosynthetic capacity, and photoprotective mechanisms. $X$. sericea exhibited a similar response to $S$. guianensis in relation to the parameters $F / F_{\mathrm{m}}, \Delta F / F_{\mathrm{m}}{ }^{\prime}$, and NPQ in the EXU.
The drop in observed values of $F_{v} / F_{\mathrm{m}}$, in $X$. sericea and $S$. guianensis, in the EXU plants, is indicative of photoinhibition (Krause and Weis, 1991; Pandey et al., 2005). Reductions in the $F_{v} / F_{\mathrm{m}}$ ratio are reported as photoinhibition in tropical tree species subjected to elevated levels of irradiance (Dias and Marenco, 2007) and plants exposed to stress (Paiva et al., 2009; Gonçalves et al., 2010). One of the targets of the photoinhibitory process is the dimer D1/D2, a chief structural protein complex of PSII. The ability of a plant to regenerate from such damage will determine its capacity for supporting this stress factor (Krause and Weis, 1991; Barber and Anderson, 1992; Maxwell and Johnson, 2000; Dias and Marenco, 2006).

According to Osmond (1994) when plants are exposed to high light levels that damage the photosynthetic apparatus, the result can be chronic photoinhibition that affects both quantum efficiency as well as maximum photosynthetic rate. The chronic photoinhibition is the process in which the electron flux through the reaction center of PSII is reduced because of the irreversible D1-D2 heterodimer protein inactivation and/or reaction center of PSII disassembly. In strongly photoinhibited leaves, most of the xanthophyll cycle carotenoids are retained as violaxanthin and so low levels of sustained thermal energy dissipation decrease the maximum photosynthetic rate (Alves et al., 2002). On the other hand, the term dynamic photoinhibition (Osmond, 1994) has been adopted to describe the transient and rapidly reversible decreases in maximal PSII quantum efficiency. Dynamic photoinhibition is a photoprotective energy dissipation process involving the xanthophyll cycle in the absorbed light dissipation as heat without changing the rates of photosynthetic electron transport and maintaining the maximal photosynthetic rate (Adams III et al., 2006). Dynamic photoinhibition is typically attributed to midday depressions in the photosynthetic yield occurring between noon and the early afternoon hours. This process involves the regulation of photosynthetic quantum yield in a very predictable manner over the course of the day by thermal dissipation of excess energy from the xanthophyll cycle that represents the non-photochemical quencher (NPQ) (Demmig Adams and Adams III, 1992; Adams III et al., 2006). Thus the results of the present study suggest that both species suffered dynamic photoinhibition in the EXU since a reduction of the net photosynthesis rate $(A)$ was not observed despite the fall in the $F_{\mathrm{v}} / F_{\mathrm{m}}$.

The $F_{V} / F_{\mathrm{m}}$ ratio reflects the maximum quantum efficiency of the PSII and it is used as a sensitive indicator of the photosynthetic performance of the plant. According to Bjorkman and Demmig (1987), when a plant is under 
stress-free conditions, the $F_{v} / F_{\mathrm{m}}$ ratio should vary between 0.80 and 0.83 . Thus we assume that both EXU species was subject to conditions of stress during both seasons, with that stress being greater during the dry season. Nevertheless, qP values did not demonstrate a significant reduction in the plants analyzed in the exposed understory. Given that qP reflects the proportion of the open state PSII reaction centers, the high values of $\mathrm{qP}$ can result either from high rates of electron transfer around PSII or from the occurrence of high non photochemical quenching processes (Chaloub et al., 2010) and thus maintain good photosystem health (Lage-Pinto et al., 2008).

The same response pattern was verified for the $F_{\mathrm{m}} / F_{0}$ ratio in the studied plants. According to Reigosa and Weiss (2001), this ratio bears a direct relation with the water potential of the plant. Under conditions of severe water stress, this ratio can be reduced to as low as 1 (with no production of $F_{\mathrm{v}}$ ). Thus we suggest that both species presented water stress in the EXU in the dry season, a pattern that was unconfirmed in the other environments studied. These data are corroborated by the significant decrease in the quantum yield of the PSII $\left(F_{v} / F_{m}\right)$ in the EXU during the dry period, which also indicates that the plants have responded to the effects of water stress (Baker, 1993). The relationship between the water deficit and the enhancement of photoinhibition was reported by several authors (Alves et al., 2002, Pastenes et al., 2005, Zhou et al., 2007).

Plants are susceptible to photoinhibition particularly when high light occurs in conjunction with other stressful environmental conditions, such as low water availability. This occurs, for example, when the eucalyptus monodominant plantation trees were removed (EXU), or where there is little canopy vegetation (ECU) to prevent light penetration. In these cases of major light penetration there is rapid evaporation of soil water (Cornic, 1994).

However, plants have different mechanisms to prevent or tolerate photoinhibition. According to Alves et al. (2002), photoprotection can be prevented by accessory pigments, such as carotenoids, which act as a protective system, since they prevent ROS formation. Carotenoids also help in the dissipation of excess absorbed energy as heat. The authors also mention the importance of metabolic pathways such as antioxidant enzymes and a rapid response to excessive irradiation. This response is characterized by an increase in thermal dissipation in the antenna and/or reaction center of PSII associated with the generation of transthylakoidal potential $(\Delta \mathrm{pH})$.

The results of the NPQ parameter suggest that during the dry season there was an increase in heat dissipation in the plants of $X$. sericea in the EXU. In a study of Phaseolus vulgaris (L.), Santos et al. (2009) also registered higher $N P Q$ values under conditions of increased light intensity and water stress. In leaves, the dissipation of the energy available through other processes beyond those related to the photosynthetic metabolism of carbon (such as heat) is an important defense mechanism in the presence of water stress or natural conditions (Chaves et al., 2002). The NPQ is among the chief mechanisms used to prevent or reduce the damage caused by the excess of light energy that reaches the photosynthetic apparatus (Maxwell and Johnson, 2000).

The presence of lower levels of chlorophyll $a, b$, and total chlorophylls in the EXU is corroborated by the findings of Morais et al. (2007), who also observed lower levels of these pigments in tropical tree species (Bertholletia excelsa, Carapa guianensis, and Dipteryx odorata) exposed to increased light intensity. Chlorophyll is constantly synthesized and destroyed in the presence of light (photo-oxidation), but under high light intensity there is a higher rate of decomposition, with the established equilibrium occurring at a lower concentration (Kramer and Kozlowski, 1979). Thus plants exposed to high light intensities exhibited reduced levels of chlorophyll when compared with plants subjected to moderate lighting (Boardman, 1977). A higher level of carotenoids was observed in the dry season in relation to the rainy season in the ECU for S. guianensis. Silva et al. (2010) obtained similar findings for Byrsonima sericea in the REBIO União, suggesting that the increase in pigment content in the dry season may have occurred due to lower relative water content in the leaves caused by the decrease in water availability during this season.

The total chlorophyll/carotenoid ratio was lower in the EXU for both species. These results are corroborated by Sarijeva et al. (2007), who studied Ginko biloba L. and Fagus sylvatica L., and by Silva et al. (2010), who studied Byrsonima sericea in contrasting light environments. Accumulating more carotenoids is a physiological strategy for the protection of plants against photoinhibition because these pigments efficiently dissipate the excess of solar radiation in a non-destructive manner, avoiding damage to the PSII (Demmig-Adams et al., 1989), which in turn corroborate the non-photochemical (NPQ) dissipation data discussed above. NPQ is basically related to the dissipation of the excess light energy in the form of heat in the level of PSII (Ruban and Horton, 1995).

Though $S$. guianensis in the EXU did not exhibit significant difference in the chlorophyll $a$ and $b$ contents between the dry and rainy season, the carotenoid levels 
were greater during the dry season, while the total chlorophyll/carotenoid ratio was lower. These results suggest that in addition to light intensity, water availability is also an important factor that influences carotenoid content in $S$. guianensis. The species $X$. sericea presented seasonal variation in pigment levels with responses similar to those verified in $S$. guianensis only in the ECU.

Though both species belong to early stages of ecological succession, they still exhibited dynamic photoinhibition after 1 year of exposure to full sunlight (EXU) in both the seasons, but more markedly so in the dry season. In general, both species presented similar photosynthetic responses in relation to environments. Based on these results, in a context of management actions for tropical environments, it is possible to suggest in phases of restoration that: (1) these species are indicated for planting in degraded areas due to its high resistance to dry and high light intensity conditions; and 2) considering that the species present higher degrees of photoinhibition during the dry season, it is recommended that the cutting of eucalyptus trees as management practice should be performed in a gradual manner, during the rainy season, in order to minimize stress on these species.

Acknowledgements: The authors cordially extend thanks to Coordination for the Improvement of Higher Education Personnel (CAPES) for the principal author's doctorate fellowship, which helped make this work possible; to biologist $D$ R Ribeiro, and to the REBIO União (ICMBio) for its concession of meteorological data and permission to conduct this research.

\section{REFERENCES}

Adams III WW, Zarter CR, Mueh KE, Amiard V, Demmig-Adams B (2006) Energy dissipation and photoinhibition: a continuum of photoprotection. In: Demmig-Adams B, Adams III WW, Mattoo A, editors. Photoprotection, photoinhibition, gene regulation, and environment. The Netherlands, Springer. v. 21, pp. 49-64.

Alves PLCA, Magalhães ACN, Barja PR (2002) The phenomenon of photoinhibition of photosynthesis and its importance in reforestation. Bot. Rev. 68:193-208.

Bacha CJC, Barros ALMB (2004) Reflorestamento no Brasil: evolução recente e perspectivas para o futuro. Sci. For. 66:191-203.

Baker MG, Press MC, Brown ND (1997) Photosynthetic characteristics of dipterocarp young plants in three tropical rain forest light environments: A basis for niche partitioning. Oecologia 122:453-463.

Baker NR (1993) Light-use efficiency and photoinhibition of photosynthesis in plants under environmental stress. In: Smith, JAC, Griffiths, H, editors. Water deficit plant responses from cell to community. Oxford: Bios Scientific Publishers. pp. 221-235.
Barber J, Andersson B (1992) Too much of a good thing: light can be bad for photosynthesis. Trends Biochem. Sci. 17:61-66.

Bilger W, Schreiber U, Bock M (1995) Determination of the quantum efficiency of photosystem II and of non-photochemical quenching of chlorophyll fluorescence in the field. Oecologia 102:425-432.

Bjorkman 0, Demmig B (1987) Photon yield for 02 evolution and chlorophyll fluorescence characteristics a $77 \mathrm{~K}$ among vascular plants of diverse origins. Planta 170:489-504.

Boardman NK (1977) Comparative photosynthesis of sun and shade plants. Annu. Rev. Plant Physiol. 28:355-377.

Castro Y, Fetcher N, Fernandez DS (1995) Chronic photoinhibition in seedling of tropical trees. Physiol. Plant. 94:560-565.

Chaloub RM, Reinert F, Nassar CAG, Fleury BG, Mantuano DG, Larkum AWD (2010) Photosynthetic properties of three Brazilian seaweeds. Rev. Bras. Bot. 33:371-374.

Chaves MM, Pereira JS, Maroco J, Rodrigues ML, Ricardo PP, Osório $\mathrm{ML}$, et al (2002) How plants cope with water stress in the field. Photosynthesis and growth. Ann. Bot. 89:907-916.

Cornic G (1994) Drought stress and high light effects on leaf photosynthesis In: Baker NR, editor. Photoinhibition of photosynthesis: from molecular mechanisms to the field. Oxford: Bios. Scientific. Publishers. pp.297-311.

Costa GF, Marenco RA (2007) Fotossíntese, condutância estomática e potencial hídrico foliar em árvores jovens de andiroba (Carapa guianensis). Acta. Amaz. 37:229-234.

Demmig-Adams B, Adams III WW (1992) Carotenoid composition in sun and shade leaves of plants with different life forms. Plant Cell Environ. 15:411-419.

Demmig-Adams B, Adams III WW, Barker DH, Logan BA, Bowling DR, Verhoeven AS (1996) Using chlorophyll fluorescence to access the fraction of absorbed light allocated to thermal dissipation of excess excitation. Physiol. Plant. 98:253-264.

Demmig-Adams B, Winter K, Kruger A, Czygan FC (1989) Light response of CO2 assimilation, dissipation of excess excitation energy, and zeaxanthin content of sun and shade leaves. Plant Physiol. 90:881-886.

Dias DP, Marenco RA (2007) Fotossíntese e fotoinibição em mogno e acariquara em função da luminosidade e temperatura foliar. Pesq. Agropec. Bras. 42:305-311.

Dias DP, Marenco RA (2006) Photoinhibition of photosynthesis in Minquartia guianensis and Swietenia macrophylla inferred by monitoring the initial fluorescence. Photosynthetica 44:235-240.

Eschenbach C, Glauner R, Kleine M, Kappen L (1998) Photosynthesis rates of selected tree species in lowland dipterocarp rainforest of Sabah, Malaysia. Trees. Struct. Funct. 12:356-365.

Evaristo VT, Braga JMA, Nascimento MT (2011) Atlantic Forest regeneration in abandoned plantations of eucalypt (Corymbia citriodora) in Rio de Janeiro, Brazil. Interciencia 36:431-436.

Faria T, Garcia-Plazaola JI, Abadia A, Cerasoli S, Pereira JS, Chaves MM (1996) Diurnal changes in phtoprotective mechanisms in leaves of cork oak (Quercus suber) during summer. Tree Physiol. 16:115-123.

Faria T, Silvério D, Breia E, Cabral R, Abadía A, Abadía J, et al (1998) Differences in the response of carbon assimilation to summer stress (water deficits, high light and temperature) in four Mediterranean tree species. Physiol. Plant. 102:419-428.

Fonseca CR, Ganade G, Baldissera R, Becker CG, Boelter CR, Brescovit $A D$, et al (2009) Towards an ecologically-sustainable forestry in the Atlantic Forest. Biol. Conserv. 142:1209-1219. 
Genty B, Briantais J-M, Baker NR (1989) The relationship between the quantum yield of photosynthetic electron transport and quenching of chlorophyll fluorescence. Biochim. Biophys. Acta 990:87-92.

Gonçalves JFC, Santos Jr UM, Nina Jr, AR, Chevreuil LR (2007) Energetic flux and performance index in copaiba (Copaifera multijuga Hayne) and mahogany (Swietenia macrophylla King) seedlings under two irradiance environments. Braz. J. Plant. Physiol. 19:171-184.

Gonçalves JFC, Silva CE, Guimarães DG, Bernarde RS (2010) Analysis of chlorophyll a fluorescence transients of young plants of Carapa guianensis and Dipteryx odorata submitted to two light environments. Acta. Amaz. 40:89-98.

Gonçalves JFC, Silva CEM, Gato GD (2009) Photosynthesis and water potential of andiroba seedlings submitted to water stress and rewetting. Pesq. Agropec. Bras. 44:8-14.

Hsiao TC (1973) Plant responses to water stress. Annu. Rev. Plant Physiol. Plant Mol. Biol. 24:519-570.

Instituto Brasileiro de Geografia e Estatística (IBGE) (1992) Manual técnico da vegetação brasileira. Série Manuais Técnicos em Geociências 1. Rio de Janeiro: IBGE.

Kramer T, Kozlowski T (1979) Physiology of wood plants. New York: Academic Press.

Krause GH, Weis E (1991) Chlorophyll fluorescence and photosynthesis: the basics. Annu. Rev. Plant Physiol. Plant Mol. Biol. 42:313-349.

Lage-Pinto F, Oliveira JG, Da Cunha M, Souza CMM, Rezende CE, Azevedo RA, et al (2008) Chlorophyll a fluorescence and ultrastructural changes in chloroplast of water hyacinth as indicators of environmental stress. Environ. Exp. Bot. 64:307-313.

Lichtenthaler HK, Burkart S (1999) Photosynthesis and high light stress. Bulg. J. Plant Physiol. 25:3-16.

Marenco RA, Gonçalves JFC, Vieira G (2001) Leaf gas exchange and carbohydrates in tropical trees differing in successional status in two light environments in central Amazonia. Tree Physiol. 21:1311-1318.

Marenco RA, Lopes NF (2007) Fisiologia vegetal: fotossíntese, respiração, relações hídricas e nutrição mineral. 2a. ed. Viçosa: UFV.

Marenco RA, Siebke K, Farquhar GD, Ball MC (2006) Hydraulically based stomatal oscillations and stomatal patchiness in Gossypium hirsutum. Funct. Plant Biol. 33:1103-1113.

Maxwell K, Johnson GN (2000) Chlorophyll fluorescence - a practical guide. J. Exp. Bot. 51:659-668.

Miranda CC, Canellas LP, Nascimento MT (2007) Quality of soil organic matter in fragments of Atlantic Forest and abandoned eucalyptus plantations. Rev. Bras. Ciên. Solo 31:905-916.

Morais RR, Gonçalves JFC, Santos Jr UM, Dünisch 0, Santos ALW (2007) Chloroplastid pigment contents and chlorophyll a fluorescence in Amazonian tropical three species. Rev. Árvore 31:959-966.

Myers N, Mittermeier RA, Mittermeier CG, Fonseca GAB, Kent J (2000) Biodiversity hotspots for conservation priorities. Nature 403:853-858.

Osmond CB (1994) What is photoinhibition? Some insights from comparisons of shade and sun plants. In: Baker NR, Bowyer JR, editors. Photoinhibition of photosynthesis, from molecular mechanisms to the field. Oxford: Bios Scientific. pp.1-24.

Paiva L, Oliveira JG, Azevedo RA, Ribeiro DR, Da Silva M, Vitoria AP (2009) Ecophysiological responses of water hyacinth exposed to $\mathrm{Cr}^{3+}$ and $\mathrm{Cr}^{6+}$. Environ. Exp. Bot. 65:403-409.

Pandey DM, Kang K-H, Yeo U-D (2005) Effects of excessive photon on the photosynthetic pigments and violaxanthin de-epoxidase activity in the xanthophylls cycle of spinach leaf. Plant Sci. 168:161-166.

Pastenes C, Pimentel P, Lillo J (2005) Leaf movements and photoinhibition in relation to water stress in field-grown beans. J. Exp. Bot. 56:425-433.

Prado CHBA, Wenhui Z, Rojas MHC, Souza GM (2004) Seasonal leaf gas exchange and water potential in a woody cerrado species community. Braz. J. Plant. Physiol. 16:7-16.

Reigosa MJR, Weiss 0 (2001) Fluorescence techniques. In: Reigosa MJR, editor. Handbook of plant ecophysiology techniques. Netherlands: Kluwer Academic Publishers. pp.155-171.

Ruban AV, Horton P (1995) Regulation of non-photochemical quenching of chlorophyll fluorescence in plants. Austr. J. Plant Physiol. 22:221-230.

Santos Jr UM, Gonçalves JFC, Feldpausch, TR (2006) Growth, leaf nutrient concentration and photosynthetic nutrient use efficiency in tropical tree species planted in degraded areas in central Amazonia. Forest. Ecol. Man. 226:299-309.

Santos MG, Ribeiro RV, Machado EC, Pimentel C (2009) Photosynthetic parameters and leaf water potential of Five common bean genotypes under mild water deficit. Biol. Plant. 53:229-236.

Sarijeva G, Knapp M, Lichtenthaler HK (2007) Differences in photosynthetic activity, chlorophyll and carotenoid levels, and in cholorophyll fluorescence parameters in green sun and shade leaves of Ginkgo and Fagus. J. Plant Physiol. 164:950-955.

Silva SS, Oliveira JG, DaCunha M, Vitória AP (2010) Photosynthetic performance and anatomical adaptations in Byrsonima sericea DC. under contrasting light conditions in a remnant of the Atlantic forest. Braz. J. Plant. Physiol. 22:245-254.

SOS Mata Atlântica. Instituto Nacional de Pesquisas Espaciais (INPE) (2001) Atlas dos remanescentes florestais da Mata Atlântica do Estado do Rio de Janeiro. Período de 1995-2000. São Paulo: Fundação SOS Mata Atlântica e INPE.

Van Kooten 0, Snel JFH (1990) The use of chlorophyll fluorescence nomenclature in plant stress physiology. Photosynth. Res. 25:147-150.

Wellburn AR (1994) The spectral determination of chlorophylls $a$ and $b$, as well as total carotenoids, using various solvents with spectrophotometers of different resolution. Plant Physiol. 144:307-313.

Zar JH (1996) Biostatistical analysis. 3rd ed. New Jersey: Prentice-Hall.

Zhou Y, Lam, HM, Zhang J (2007) Inhibition of photosynthesis and energy dissipation induced by water and high light stresses in rice. J. Exp. Bot. 58:1207-1217. 